\section{Air pollution and respiratory diseases in the Municipality of Vitória, Espírito Santo State, Brazil}

\author{
Doenças respiratórias e poluição atmosférica no \\ Município de Vitória, Espírito Santo, Brasil
}

\author{
1 Escola Nacional de Saúde \\ Pública Sergio Arouca, \\ Fundação Oswaldo Cruz, \\ Rio de Janeiro, Brasil. \\ 2 Instituto de Medicina \\ Social, Universidade do \\ Estado do Rio de Janeiro, \\ Rio de Janeiro, Brasil. \\ 3 Instituto Estadual de Meio \\ Ambiente e Recursos Hídricos \\ do Espírito Santo, Vitória, \\ Brasil. \\ Correspondence \\ H. A. Castro \\ Centro de Estudos da Saúde \\ do Trabalhador e Ecologia \\ Humana, Escola Nacional de \\ Saúde Pública Sergio Arouca \\ Fundação Oswaldo Cruz. \\ Rua Leopoldo Bulhões 1480, \\ Rio de Janeiro, $R J$ \\ 21041-210, Brasil. \\ castro@ensp.fiocruz.br
}

\begin{abstract}
In Brazil, increasing air pollution in urban areas has led to a rise in respiratory diseases among children and the elderly and has also been the main cause of hospital admissions. This study aims to evaluate the air pollution levels in Vitória, capital of Espírito Santo State, Brazil, in comparison to Brazilian legislation and recent World Health Organization (WHO) guidelines, analyzing the spatial distribution of asthma cases treated at local outpatient services. A descriptive epidemiological study was performed with daily records on air pollution and outpatient treatment for respiratory diseases from 2001 to 2003, for children under 6 years of age. A geographic information system (GIS) was used to identify asthma distribution in the municipality. Air pollution levels were relatively low when compared to the Brazilian legislation and WHO guidelines. Only mean $\mathrm{PM}_{10}$ and $\mathrm{NO}_{2}$ exceeded the annual quality standard. The three highest asthma outpatient treatment rates were observed in the districts of São José, Jabou, and Morro do Quadro.
\end{abstract}

Respiratory Tract Diseases; Air Pollution; Information Systems

\author{
Hermano Albuquerque de Castro 1 \\ Sandra Hacon 1 \\ Roberta Argento 1 \\ Washington Leite Junger 2 \\ Carla F. de Mello 1 \\ Nilson Castiglioni Júnior 3 \\ José Gustavo da Costa ${ }^{3}$
}

\section{Introduction}

In developing countries, increasing air pollution in urban areas has led to a rise in acute respiratory diseases in children and has been the main cause of hospital admissions in urban areas 1,2. The main sources of air pollution in urban areas are: vehicle exhaust, caused by old cars and heavy vehicles, industrial pollution, road dust, and solid waste incineration. Typical Brazilian urban air pollution measurement includes particulate matter (PM), gas pollutants like ozone $\left(\mathrm{O}_{3}\right)$, carbon monoxide $(\mathrm{CO})$, nitrogen oxides $\left(\mathrm{NO}_{\mathrm{x}}\right)$, and sulfur dioxide $\left(\mathrm{SO}_{2}\right)$, and airborne toxic chemicals like hydrocarbons and aldehydes. Particle size, surface area, and chemical composition determine the health risk posed by PM. Fine and ultrafine particles $(0.005$ $1 \mu \mathrm{m}$ in diameter), the main components of vehicle emissions, are emitted from diesel engine sources (e.g., buses). They penetrate deeper into lung tissues and are believed to be associated with adverse health effects ${ }^{3}$. Although diesel engines emit less $\mathrm{CO}$ than gasoline engines, their emissions of $\mathrm{NO}_{2}$ and fine and ultrafine particles are ten times greater and one hundred times higher, respectively, than the emissions from gasoline-powered vehicles 4 .

The adverse health effects of air pollution include not only clinical outcomes, such as hospital admissions, loss of pulmonary function, and mortality, but also reduced quality of life, inter- 
fering with daily activities. Studies on air pollution and human health effects documented in the literature are mainly acute time series that have shown associations between particulate pollution and daily hospital admissions (especially asthma among children and chronic obstructive pulmonary disease in the elderly) ${ }^{5}$. In Brazil, mean asthma prevalence in children is $20 \%$. It is the fourth cause of hospital admissions, with an estimated 350,000 cases $(2.3 \%$ of total admissions for all causes) 6 and is regarded as a serious public health problem.

The establishment of industrial plants like CVRD and the Tubarão Steel Company (CST), a paper mill, and a large complex of seven seaports in the State of Espírito Santo resulted from an industrialization process in the region that now accounts for $25 \%$ of the total cargo volume transported in the area (Espírito Santo State Environmental Secretariat. http://www. seama.es.gov.br/scripts/sea0501.asp, accessed on 03/Mar/2006). Factories in Greater Vitoria discharge $34 \%$ of the particulate matter into the atmosphere 7 . This region is also affected by vehicle emissions, a relevant fraction of urban air pollution, where approximately 373,050 vehicles circulate daily (Espírito Santo State Transit Department. http://www.detran.es.gov.br, accessed on $20 / \mathrm{Feb} / 2006$ ).

The region currently boasts solid economic diversity, and $60 \%$ of all industries with high pollution potential in the State of Espírito Santo are operating in a region known as Greater Metropolitan Vitoria (Espírito Santo State Environmental Secretariat. http://www.seama.es.gov.br/scripts/ sea0501.asp, accessed on 03/Mar/2006), which includes seven municipalities with an estimated population of $1,439,596,90 \%$ of whom living in urban areas and with nearly $42 \%$ of the State's total population.

In this study, Greater Vitoria was assumed to be the source of air pollution, since there are no known geographic barriers that prevent pollutants from dispersing. The population in Vitória is exposed to the same pollutants found in the surrounding area, but air pollutant levels vary according to the distance from the sources.

This study was developed in one of the pilot areas for environment health surveillance related to an air pollution control program under the Brazilian Ministry of Health (http://portal.saude. gov.br/portal/svs, accessed on 18/Apr/2006).

The paper addresses the relevance of environmental air quality in Vitória, with emphasis on $\mathrm{PM}_{10}$, comparing the concentrations of pollutants in Vitória with the Brazilian air quality standards and WHO air quality guidelines. The study also compares the pattern of asthma spa- tial distribution among children treated at outpatient services from 2001 to 2003 in Vitória. This article reports on the first phase of a more complete study conducted in the city of Vitória on the health risk of exposure to air pollutants.

\section{Material and methods}

An ecological study using daily records on air pollution and outpatient treatment for respiratory diseases was performed from 2001 to 2003 in the municipality of Vitória. There were 293,305 inhabitants in an area of $93 \mathrm{~km}^{2}$, corresponding to 3,154 inhabitants per square kilometer, with the highest population density in the State of Espírito Santo and some $50 \%$ of the State's entire industrial activity (Vitória Municipal Government. http:// www.vitoria.es.gov.br/negocios/investe.htm, accessed on 08/Apr/2006). Vitória has the second highest annual per capita income of all the Brazilian State capitals, with $\mathrm{R} \$ 1,588.00$, and a human development index (HDI) of 0.856 (Vitória Municipal Government. http://www.vitoria. es.gov.br/indicadores/203.htm, accessed on 08/ Apr/2006).

Vitória is located at latitude South $20^{\circ} 19^{\prime} 9^{\prime \prime}$ and longitude West $40^{\circ} 20^{\prime} 50^{\prime \prime}$ and borders on the cities of Serra to the North, Vila Velha to the South, Cariacica to the West, and the Atlantic Ocean to the East. It is an extension of continental land consisting of a mountainous island with the same name and several mangrove and salt marsh areas (Jones dos Santos Neves Institute for Research and Development. http://www.ipes.es.gov.br, accessed on 01/May/2006), resulting from the retreat of ocean levels. The location of the study area is shown in Figure 1.

\section{Data source}

The daily records from the air quality monitoring program were provided by the State Environmental Secretariat (SEAMA) and State Environmental Institute (IEMA), and outpatient records on respiratory diseases were furnished by the Municipal Health Secretariat. Daily records on respiratory diseases were obtained from the Unified Productivity Bulletin (UPB), a registry used by 27 primary health units in the municipality of Vitória, which is the only municipality that uses this kind of outpatient registry. Both data sets referred to January 1, 2001, to December 31, 2003.

The UPB was established in the early 1990s with the aim of providing information related to population morbidity at outpatient services. This type of registry presents individual data on 
Figure 1

Spatial distribution of outpatient asthma treatment in Vitória, Espírito Santo State, Brazil, 2001-2003.

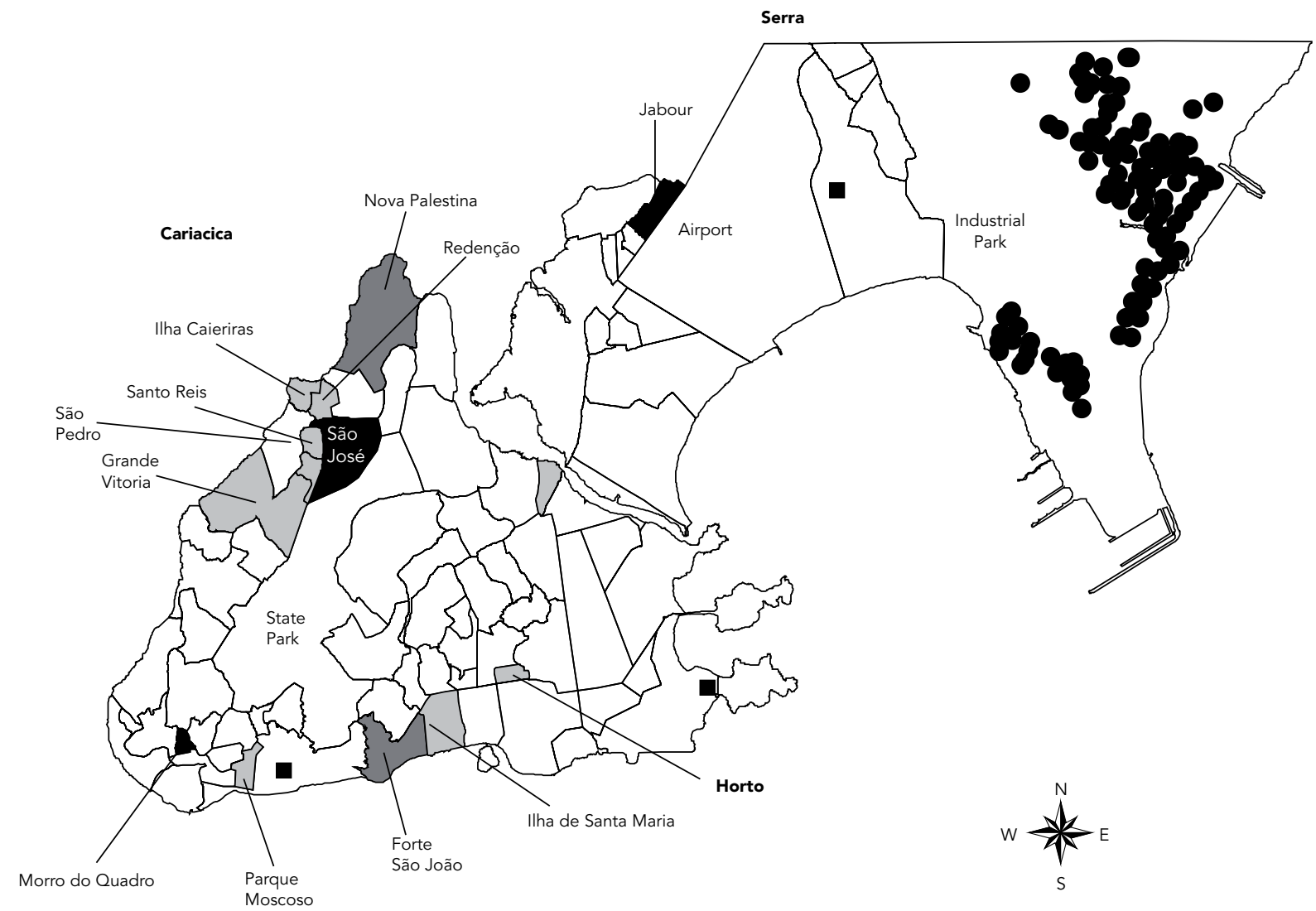

Vila Velha

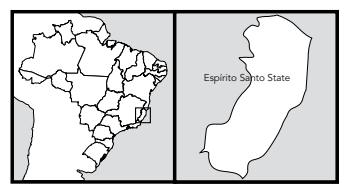

$750 \quad 1,500$
Industrial pollution source

Stations of air quality

Ambulatory attendent of asthma (under 6 years), 2001-2003

$20.00 \%-30.00 \%$

$30.01 \%-50.00 \%$

above $50 \%$ treatment in the primary health system. The information available contained date of consultation, patient's name, sex, date of birth, age, place of residence, and main diagnosis. The study analyzed respiratory diseases in general (J00-J99), pneumonia (J12-J18), and asthma (J45) for children under 6 years of age, based on the International Classification of Diseases, 10th Revision (ICD-10) 8 . The air quality program is managed by the IEMA, which is responsible for five automatic monitoring stations that provided daily records of $\mathrm{CO}$ (8-hour averages), $\mathrm{SO}_{2}$ (24-hour averages); particulate matter with an aerodynamic profile $\leq 10 \mu g\left(\mathrm{PM}_{10}-24\right.$-hour averages $)$; and $\mathrm{O}_{3}$ and $\mathrm{NO}_{2}$ (one-hour means), for Greater Vitória. The IEMA also provides daily records on minimum, average, and maximum daily temperatures and relative humidity. However, only one weather station 
provided measurements of temperature, humidity, and wind direction for all of Vitória. The daily air pollutant concentrations measured in Vitória were compared to the National Environmental Council (CONAMA) standard ${ }^{9}$ and WHO air quality guidelines for $\mathrm{PM}_{10}, \mathrm{SO}_{2}, \mathrm{NO}_{2}$, and $\mathrm{O}_{3} 10$.

\section{Geographic analysis of asthma in children under 6 years}

Population group exposure assessment is based on linkage of environmental and health data, in which geographic information systems can be used as a basis for organizing health-related and environmental data sets 11 . This relationship can be difficult to establish due to spatial and temporal lags in data sets. In this study, the local analytical unit referred to the districts and the group of children with respiratory diseases, spatially distributed (Vitória Municipal Government. http://www.vitoria.es.gov.br/secretarias/sedec/ home.htm, accessed on 08/Apr/2006). The air quality referred to the average $\mathrm{PM}_{10}$ concentration for 2001-2003.

The aim of the geographic analysis was to identify an asthma distribution pattern in relation to the mean $\mathrm{PM}_{10}$ in Vitória. The first step was to use a cartographic base (generation year: 2000) provided by the Municipal Environmental Secretariat in dxf format to process information for Vitória districts and converted to a shp format. Choice of districts as spatial units was due to the fact that daily outpatient care is recorded by district.

Outpatient treatment includes emergencies and routine cases for all diseases. For this study, respiratory disease data were filtered from the main database. All respiratory diseases were diagnosed clinically and reported to UPB by the attending health professionals. Absolute asthma numbers in children under 6 years of age were selected from daily records in the respiratory disease database. The number of asthma outpatient consultations was calculated monthly per district and year and grouped by season.

Secondary demographic data were obtained from the 2000 census (http://www.ibge.gov.br, accessed on 08/Jan/2007) available in digital format at the Vitória Municipal Development Secretariat. The municipality was divided by district and the outpatient treatment rates were calculated using the DATASUS database ${ }^{8}$ per age bracket and home address. Calculating the target child population required: (i) estimating the percentage of children under 6 years of age in Vitória; (ii) imputing this information to districts (assuming a linear pattern in the districts).
Asthma outpatient treatment rates in children were obtained from the number of asthma cases recorded per district per year divided by the total population under 6 years of age in the same year, multiplied by 100 inhabitants.

An asthma distribution map was developed for Vitória using ArcGis (http://www.esri.com/ software/arcgis/index.html) with the estimated rates in children under 6 from 2001 to 2003.

\section{Results}

Table 1 presents the results of the descriptive analysis of variables. During the study period, only average $\mathrm{PM}_{10}$ and $\mathrm{NO}_{2}$ levels exceeded their respective CONAMA annual air quality standards of $50 \mu \mathrm{g} / \mathrm{m}^{3}$ and $100 \mu \mathrm{g} / \mathrm{m}^{3}$, respectively. The mean concentration of all pollutants in Greater Vitória was low as compared to the CONAMA Ruling ${ }^{9}$. Of all the $\mathrm{PM}_{10}$ records $(1,034)$, only $1.2 \%$ exceeded the annual air quality standard presenting the highest concentration $\left(99 \mu \mathrm{g} / \mathrm{m}^{3}\right)$ for the period. Figure 2 shows daily air pollutant concentrations in Vitória compared to the air quality standard set by the CONAMA Ruling and WHO air quality guidelines $10 . \mathrm{PM}_{10}, \mathrm{O}_{3}$, and $\mathrm{SO}_{2}$ concentrations in Vitória from 2001 to 2003 exceeded the WHO guidelines (which are stricter than the CONAMA standard) by $1.25 \%, 1 \%$, and $7.25 \%$ respectively. The updated WHO guidelines aim to support air quality improvement measures at the optimal achievable level of public health protection in different contexts. These guidelines are based on the most recent and extensive international epidemiological evidence, based largely on studies using $\mathrm{PM}_{10}$ as the exposure indicator.

Weather conditions can also influence the primary and secondary pollutant level. Vitória is located near the sea and is usually quite windy, thus increasing the air pollution dispersion and decreasing the air pollutant levels near the sources.

Table 1 shows the descriptive statistics for respiratory diseases, asthma, and pneumonia in outpatient treatment of children under 6 . The outcomes were grouped by date, providing a time series of daily frequencies for the study period. Mean outpatient treatment for all respiratory illnesses in children under 6 was 126 cases, with a peak of 582 during the autumn. Pneumonia and asthma showed a mean of 8 and 19 cases, respectively. Asthma accounted for $15 \%$ of all respiratory cases in children younger than 6 .

Table 2 shows the Pearson correlation coefficient $(\mathrm{p}<0.05)$ among daily pollutant concentrations at each monitoring station and the means for all stations in relation to the same pollutant at each station individually. Significant cross-cor- 
Table 1

Descriptive statistics for air quality monitoring program and principal respiratory diseases in children in Vitória, Espírito Santo State, Brazil, $2001-2003$.

\begin{tabular}{|c|c|c|c|c|c|c|}
\hline Stations & Variables & $\begin{array}{c}\text { Number of } \\
\text { days recorded }\end{array}$ & Mean $\left(\mu \mathrm{g} / \mathrm{m}^{3}\right)$ & Median $\left(\mu \mathrm{g} / \mathrm{m}^{3}\right)$ & $\mathrm{SD}\left(\mu \mathrm{g} / \mathrm{m}^{3}\right)$ & Range $\left(\mu \mathrm{g} / \mathrm{m}^{3}\right)$ \\
\hline \multirow[t]{5}{*}{ Laranjeiras } & $\mathrm{CO}$ & 1,095 & 593.2 & 561.0 & 184.3 & $220-1,861$ \\
\hline & $\mathrm{PM}_{10}$ & 1,064 & 29.0 & 27.7 & 10.6 & 7-95 \\
\hline & $\mathrm{NO}_{2}$ & 1,095 & 33.8 & 32.0 & 13.5 & $10-100$ \\
\hline & $\mathrm{SO}_{2}$ & 751 & 9.3 & 8.1 & 5.9 & $2-51$ \\
\hline & $\mathrm{O}_{3}$ & 1,090 & 53.4 & 50.8 & 17.0 & 18-131 \\
\hline \multirow[t]{5}{*}{ Enseada do Suá } & $\mathrm{CO}$ & 1,086 & 1024.4 & 942.7 & 382.1 & $358-3,157$ \\
\hline & $\mathrm{PM}_{10}$ & 1,079 & 27.8 & 26.9 & 8.2 & 6-77 \\
\hline & $\mathrm{NO}_{2}$ & 1,070 & 38.6 & 38.0 & 13.5 & $11-101$ \\
\hline & $\mathrm{SO}_{2}$ & 1,066 & 21.7 & 19.3 & 11.8 & $1-74$ \\
\hline & $\mathrm{O}_{3}$ & 1,043 & 51.0 & 49.0 & 15.9 & 12-119 \\
\hline \multirow[t]{5}{*}{ Vila Velha } & $\mathrm{CO}$ & 1,079 & 703.5 & 655.5 & 284.3 & $174-3,092$ \\
\hline & $\mathrm{PM}_{10}$ & 1,088 & 24.6 & 24.0 & 8.1 & $5-68$ \\
\hline & $\mathrm{NO}_{2}$ & 1,059 & 35.2 & 34.0 & 14.1 & $6-112$ \\
\hline & $\mathrm{SO}_{2}$ & 1,087 & 13.9 & 11.0 & 10.5 & $1-56$ \\
\hline & $\mathrm{O}_{3}$ & 1,092 & 60.2 & 57.0 & 18.0 & 20-141 \\
\hline \multirow[t]{5}{*}{ Cariacica } & $\mathrm{CO}$ & 1,067 & 557.1 & 531.3 & 246.8 & $95-1,395$ \\
\hline & $\mathrm{PM}_{10}$ & 1,034 & 39.8 & 37.2 & 15.6 & 8-106 \\
\hline & $\mathrm{NO}_{2}$ & 1,059 & 43.4 & 44.0 & 16.4 & $5-99$ \\
\hline & $\mathrm{SO}_{2}$ & 1,065 & 11.7 & 9.1 & 9.4 & $0-59$ \\
\hline & $\mathrm{O}_{3}$ & 1,002 & 50.5 & 48.0 & 15.7 & $17-121$ \\
\hline \multirow[t]{8}{*}{ Jardim Camburi } & $\mathrm{PM}_{10}$ & 1,051 & 26.4 & 25.7 & 7.4 & $7-67$ \\
\hline & $\mathrm{NO}_{2}$ & 994 & 39.6 & 38.0 & 15.1 & $8-136$ \\
\hline & $\mathrm{SO}_{2}$ & 919 & 8.5 & 7.3 & 5.2 & $1-54$ \\
\hline & & & Weather & Variables & & \\
\hline & Temperature $\left({ }^{\circ} \mathrm{C}\right)$ & 1,095 & 24.3 & 24.4 & 2.5 & $18-29$ \\
\hline & Relative humidity (\%) & 1,095 & 77.0 & 76.3 & 6.8 & $58-99$ \\
\hline & \multicolumn{6}{|c|}{ Daily outpatient treatment, respiratory diseases } \\
\hline & Health effects & $\begin{array}{c}\text { Number of } \\
\text { days recorded }\end{array}$ & $\begin{array}{l}\text { Average cases } \\
\text { for entire } \\
\text { period }\end{array}$ & $\begin{array}{c}\text { Median cases } \\
\text { for entire } \\
\text { period }\end{array}$ & SD & $\begin{array}{l}\text { Range cases } \\
\text { for the period }\end{array}$ \\
\hline \multirow[t]{3}{*}{ Vitória } & PNM6 & 1,095 & 7.9 & 7.0 & 6.5 & $0-64$ \\
\hline & ASTHMA6 & 1,095 & 18.8 & 17.0 & 11.3 & $0-96$ \\
\hline & RD6 & 1,095 & 126.0 & 119.0 & 72.1 & $5-582$ \\
\hline
\end{tabular}

PNM6: pneumonia < 6 years of age; ASTHMA6: asthma < 6 years of age; RD6: respiratory disease $<6$ years of age.

relation was observed for pollutants at different monitoring stations and the overall mean correlation for each pollutant with daily concentration values from different monitoring stations. The highest correlations were: 0.719 for $\mathrm{PM}_{10}$, between the Vila Velha and Enseada do Suá stations; 0.703 for $\mathrm{NO}_{2}$, between Jardim Camburi and Enseada do Suá; and 0.456 and 0.865 for $\mathrm{CO}$ and $\mathrm{O}_{3}$, respectively, between Vila Velha and Laranjeiras. The exception was $\mathrm{SO}_{2}$, with a negative correlation for most of the monitoring stations.
Temperature showed a low correlation with $\mathrm{PM}_{10}$ in Laranjeiras, Enseada do Suá, and Vila Velha. For the other sites, the correlation was negative. For relative humidity, with the exception of $\mathrm{NO}_{2}$ and $\mathrm{CO}$, which showed a low positive correlation, the other sites were negative for all pollutants. 
Daily air pollutant levels in Vitória, Espírito Santo State, Brazil, 2001-2003, compared to air quality guidelines from the National Environmental Council (CONAMA) ${ }^{9}$ and World Health Organization 10
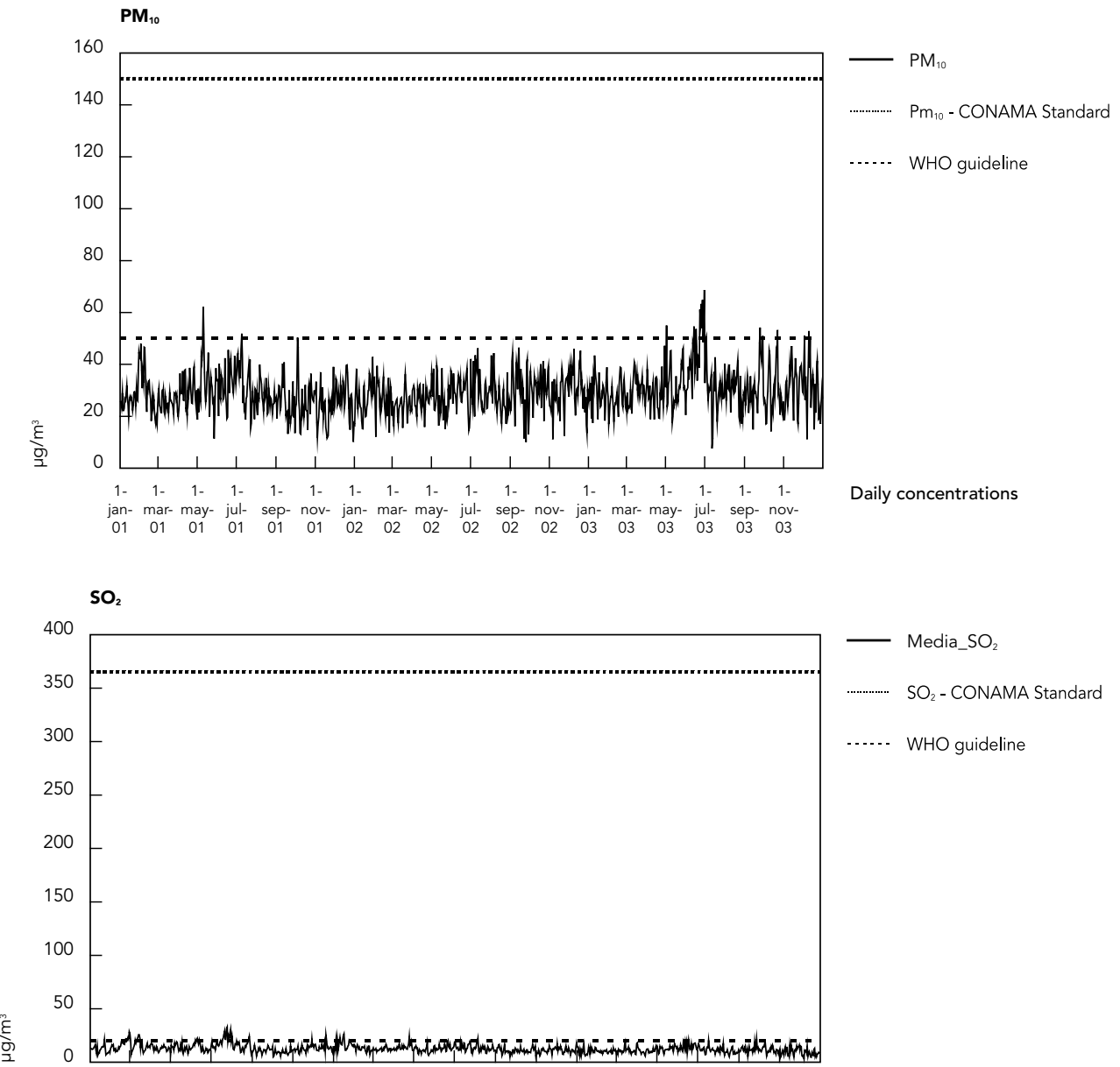
- Media_SO
……...... $\mathrm{SO}_{2}$ - CONAMA Standard WHO guideline

1- 1- 1- 1- 1- 1- 1- 1- 1- 1- 1- 1- 1- 1- 1- 1- 1- 1 -

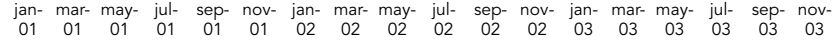
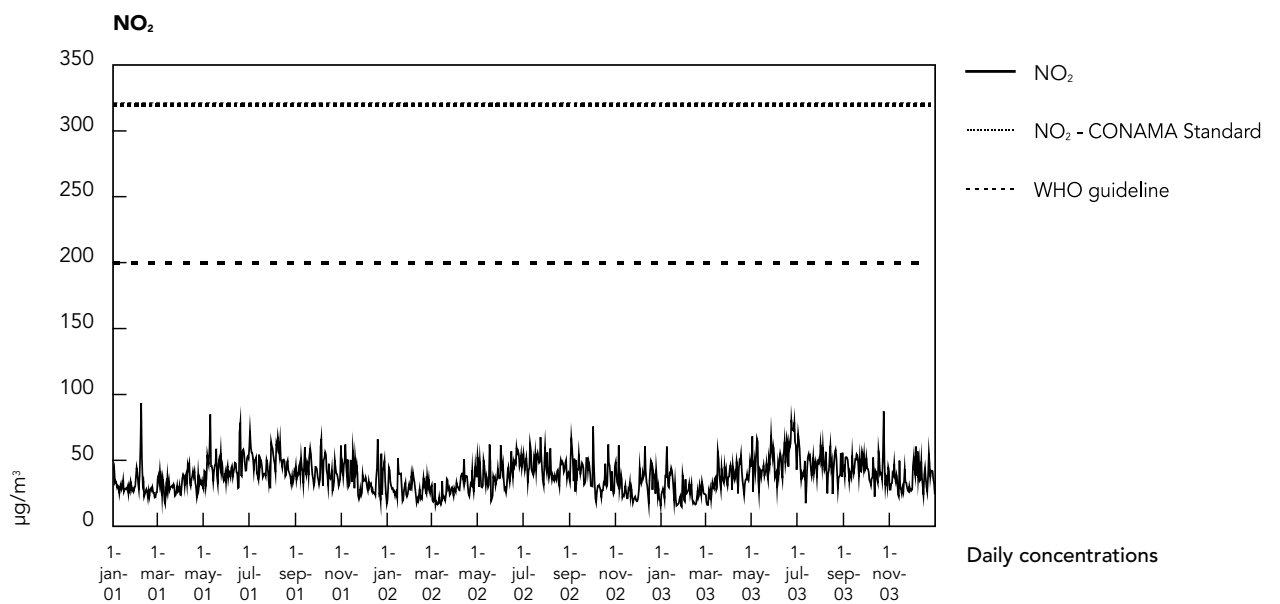
Daily air pollutant levels in Vitória, Espírito Santo State, Brazil, 2001-2003, compared to air quality guidelines from the National Environmental Council (CONAMA) ${ }^{9}$ and World Health Organization 10.

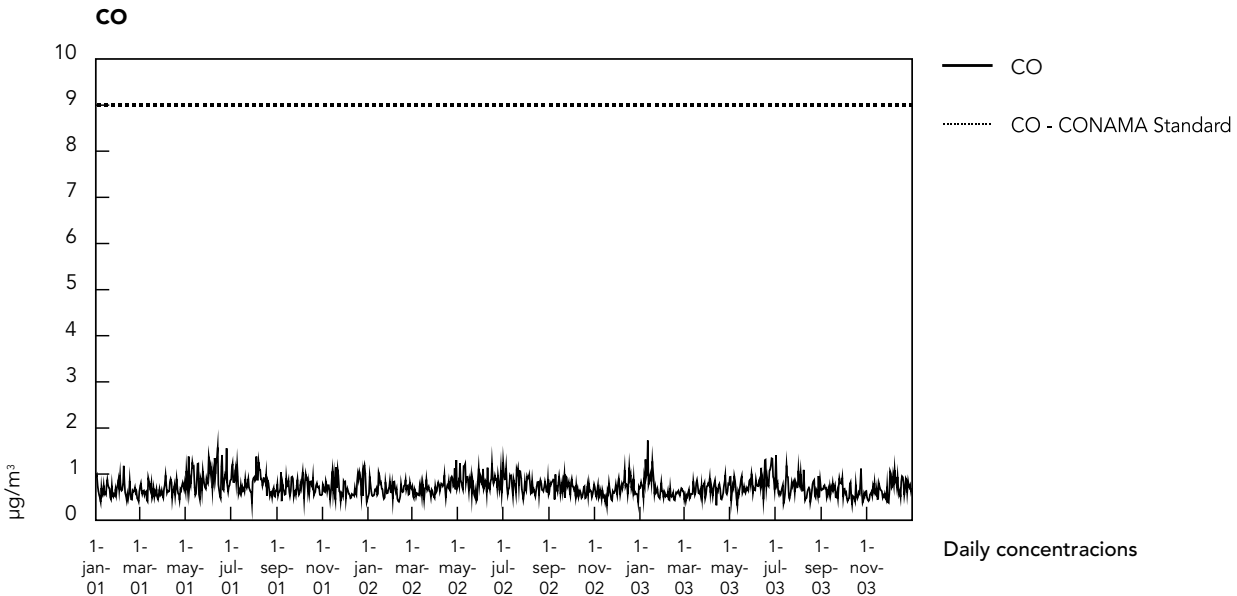

$\mathrm{O}_{3}$

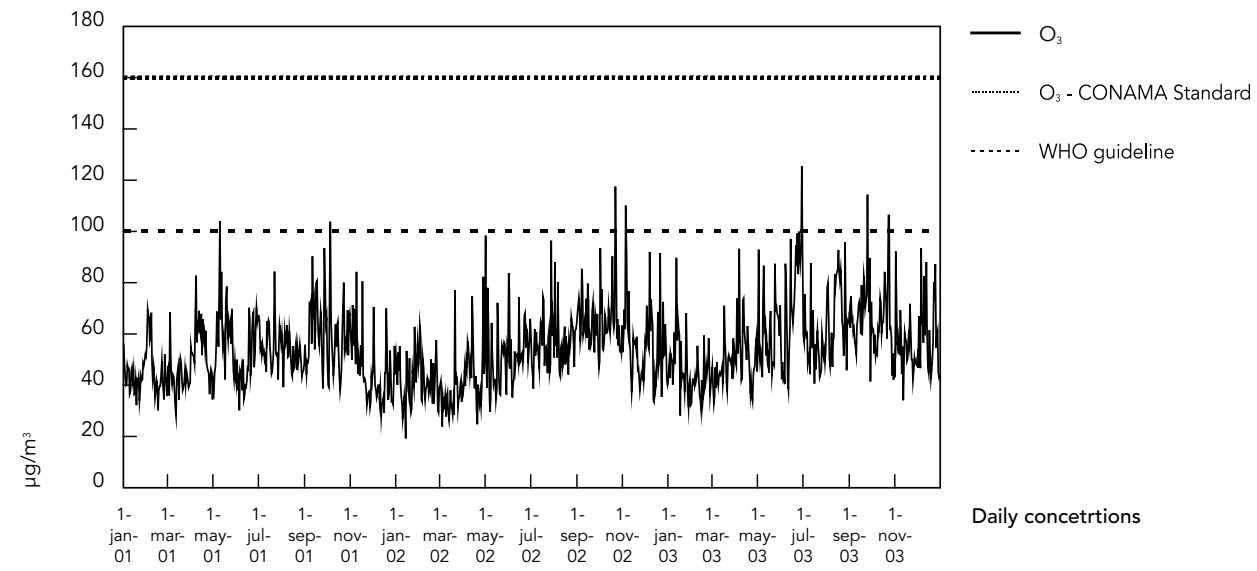

\section{Geographic analysis of asthma in under-6 children}

Considering that there was no statistically significant difference between the mean $\mathrm{PM}_{10}$ concentrations at the various air quality stations, and that $\mathrm{PM}_{10}$ showed homogeneous behavior, we assumed this variable as the main environmental exposure indicator for air quality from 2001 to 2003 in the municipality of Vitória.

Figure 3 shows the daily outpatient treatment figures for respiratory diseases in children under 6 , the mean daily levels, and the overall mean
$\mathrm{PM}_{10}$ from 2001 to $2003\left(27 \mu \mathrm{g} / \mathrm{m}^{3}\right)$. The highest $\mathrm{PM}_{10}$ levels occurred in May 2001 and from May to July 2003 , with a particularly high respiratory disease rate in 2001 .

Outpatient treatment for respiratory diseases showed a similar trend. Asthma was the main respiratory disease among children in Vitória.

Table 3 shows asthma treatment for children at health services in Vitória. Out of a total of 84 districts in the city, $16.5 \%$ showed an asthma rate greater than $20 \%$ during the study period. The districts of São José and Morro do Quadro showed a decrease of more than 50\% from 2001 to 2003. 
Pearson correlation coefficient $(-1<\mathrm{R}<1)$ and statistical significance for daily concentrations of pollutants at monitoring stations and daily means for all stations for the same pollutant and meteorological variables in Greater Metropolitan Vitória, Espírito Santo State, Brazil, $2001-2003$.

\begin{tabular}{|c|c|c|c|c|c|c|c|c|}
\hline & Stations & $\begin{array}{l}\text { Laranjeiras } \\
\text { do Suá }\end{array}$ & Enseada & Vila Velha & $\begin{array}{l}\text { Cariacica } \\
\text { Camburi }\end{array}$ & Jardim & Temperature & Humidity \\
\hline \multirow[t]{6}{*}{$\mathrm{PM}_{10}$} & Laranjeiras & 1.000 & - & - & - & - & 0.309 & -0.398 \\
\hline & Enseada do Suá & 0.615 & 1.000 & - & - & - & 0.258 & -0.252 \\
\hline & Vila Velha & 0.665 & 0.719 & 1.000 & - & - & 0.055 & -0.262 \\
\hline & Cariacica & 0.398 & 0.470 & 0.601 & 1.000 & - & -0.202 & -0.213 \\
\hline & Jardim Camburi & 0.632 & 0.612 & 0.711 & 0.646 & 1.000 & -0.026 & -0.191 \\
\hline & Mean $\mathrm{PM}_{10}$ & 0.773 & 0.795 & 0.881 & 0.802 & 0.857 & 0.064 & -0.320 \\
\hline \multirow[t]{6}{*}{$\mathrm{SO}_{2}$} & Laranjeiras & 1.000 & - & - & - & - & -0.069 & -0.009 \\
\hline & Enseada do Suá & -0.184 & 1.000 & - & - & - & 0.152 & -0.057 \\
\hline & Vila Velha & -0.241 & 0.395 & 1.000 & - & - & 0.272 & -0.166 \\
\hline & Cariacica & -0.063 & 0.122 & 0.425 & 1.000 & - & -0.181 & -0.084 \\
\hline & Jardim Camburi & 0.140 & -0.143 & -0.301 & 0.028 & 1.000 & -0.108 & -0.042 \\
\hline & Mean $\mathrm{SO}_{2}$ & 0.014 & 0.686 & 0.744 & 0.553 & 0.060 & 0.149 & -0.235 \\
\hline \multirow[t]{6}{*}{$\mathrm{NO}_{2}$} & Laranjeiras & 1.000 & - & - & - & - & -0.550 & 0.188 \\
\hline & Enseada do Suá & 0.661 & 1.000 & - & - & - & -0.541 & 0.145 \\
\hline & Vila Velha & 0.463 & 0.683 & 1.000 & - & - & -0.403 & 0.066 \\
\hline & Cariacica & 0.683 & 0.587 & 0.392 & 1.000 & - & -0.531 & 0.253 \\
\hline & Jardim Camburi & 0.671 & 0.703 & 0.530 & 0.596 & 1.000 & -0.441 & 0.187 \\
\hline & Mean $\mathrm{NO}_{2}$ & 0.845 & 0.873 & 0.739 & 0.816 & 0.852 & -0.594 & 0.207 \\
\hline \multirow[t]{5}{*}{$\mathrm{CO}$} & Laranjeiras & 1.000 & - & - & - & - & -0.186 & 0.194 \\
\hline & Enseada do Suá & 0.182 & 1.000 & - & - & - & -0.176 & 0.227 \\
\hline & Vila Velha & 0.456 & 0.376 & 1.000 & - & - & -0.023 & 0.107 \\
\hline & Cariacica & 0.383 & 0.404 & 0.223 & 1.000 & & -0.375 & 0.362 \\
\hline & Mean CO & 0.608 & 0.792 & 0.717 & 0.682 & & -0.254 & 0.302 \\
\hline \multirow[t]{5}{*}{$\mathrm{O}_{3}$} & Laranjeiras & 1.000 & - & - & - & - & -0.473 & 0.039 \\
\hline & Enseada do Suá & 0.699 & 1.000 & - & - & - & -0.245 & -0.110 \\
\hline & Vila Velha & 0.865 & 0.739 & 1.000 & - & - & -0.004 & -0.398 \\
\hline & Cariacica & 0.598 & 0.625 & 0.625 & 1.000 & - & -0.104 & -0.173 \\
\hline & Mean $\mathrm{O}_{3}$ & 0.909 & 0.870 & 0.929 & 0.808 & - & -0.371 & -0.066 \\
\hline
\end{tabular}

However, Jabour, which receives the direct impact of aircraft emissions, showed an increase of approximately $50 \%$ in asthma cases during the same period. Autumn had the highest proportion of asthma in children, reaching $88 \%$ in São José.

In the year 2001, São José inaugurated a new health service to treat the local population. Due to the generally precarious public health services in the surrounding area, parents of children from neighboring districts started declaring São José as their home address in order to tap into its new health service. This is the most likely explanation for the sudden $133 \%$ increase in asthma outpatient care in São José that year.

Figure 1 shows the study area and spatial distribution of asthma cases among children in Vitória. During the study period there was a high asthma treatment rate in the poorest dis- tricts. The three proportionally highest asthma care rates, above $50 \%$, were in São José, Jabour, and Morro do Quadro, districts that have substandard housing and local air pollution sources such as old bus depots, unpaved roads, and solid waste incineration.

\section{Discussion}

This study addressed the relevance of air quality for the population's health in Vitória and the spatial distribution of asthma cases in children as related to $\mathrm{PM}_{10}$. Based on the results, $\mathrm{PM}_{10}, \mathrm{NO}_{2}$, $\mathrm{CO}$, and $\mathrm{O}_{3}$ levels showed a homogeneous pattern among the sites. An increase in the concentration of a given pollutant indicated a linear increase for this same pollutant in all the sampling 
Figure 3

Daily pediatric outpatient treatment for respiratory diseases and mean daily PM10 in Vitória, Espírito Santo State, Brazil, 2001-2003.

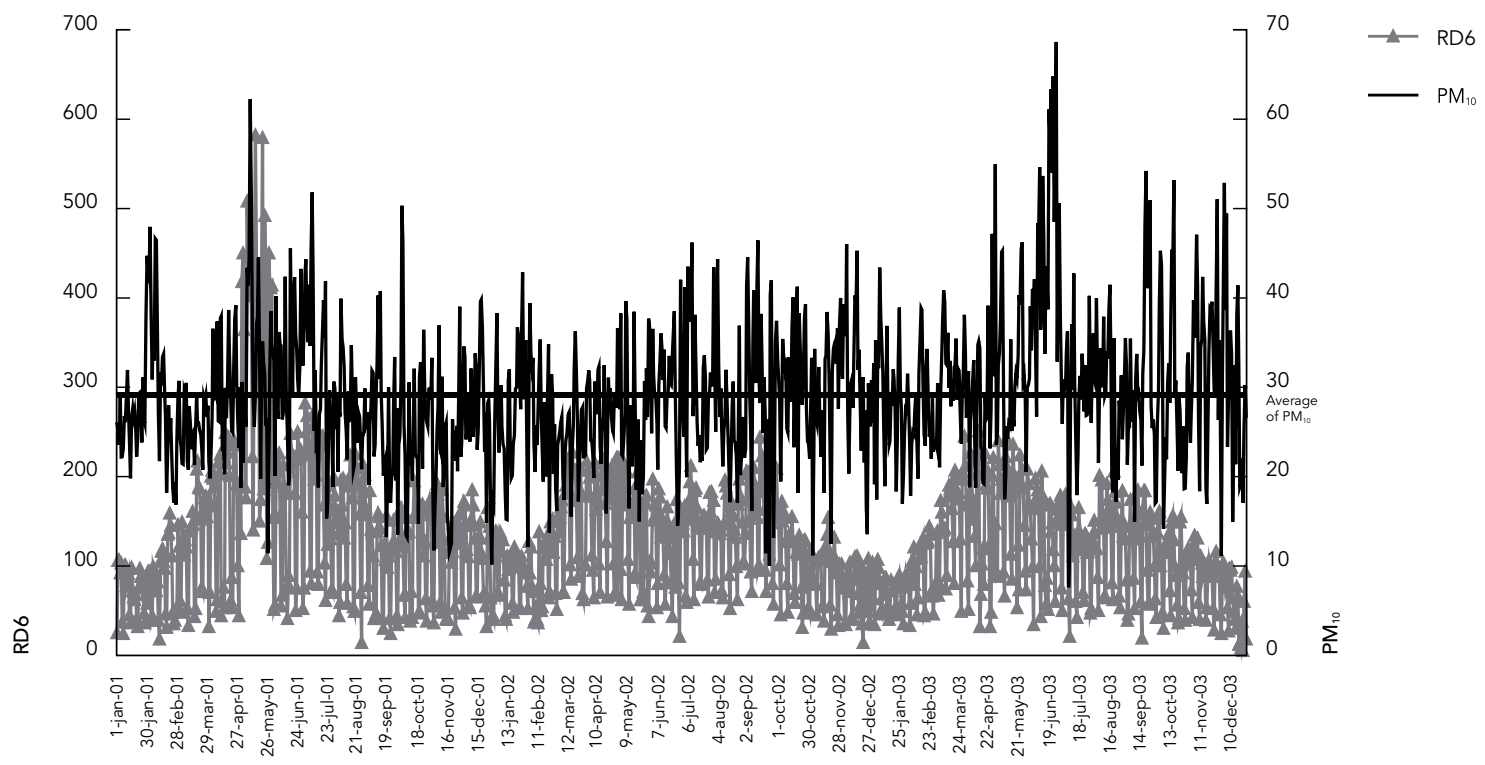

RD6: respiratory disease $<6$ years of age

Table 3

Asthma outpatient treatment rates in children under 6 years of age in districts of Vitória, Espírito Santo State, Brazil, 2001-2003.

\begin{tabular}{|c|c|c|c|c|}
\hline Districts & $\begin{array}{c}\text { Asthma outpatient } \\
\text { treatment } \\
\text { (autumn 2001) }\end{array}$ & $\begin{array}{c}\text { Asthma outpatient } \\
\text { treatment } \\
\text { (autumn 2002) }\end{array}$ & $\begin{array}{c}\text { Asthma outpatient } \\
\text { treatment } \\
\text { (autumn 2003) }\end{array}$ & $\begin{array}{c}\text { Asthma outpatient } \\
\text { treatment } \\
(2001-2003)\end{array}$ \\
\hline Ilha de Santa Maria & 17.51 & 16.32 & 26.18 & 20.00 \\
\hline Ilha Caierias & 22.85 & 16.50 & 24.61 & 21.32 \\
\hline Condusa & 21.38 & 14.48 & 28.44 & 21.43 \\
\hline Parque Moscoso & 25.49 & 22.31 & 19.06 & 22.29 \\
\hline Santo Andre & 27.91 & 18.09 & 21.21 & 22.40 \\
\hline Grande Vitória & 30.87 & 19.46 & 17.68 & 22.67 \\
\hline Santos Reis & 31.30 & 25.81 & 11.83 & 22.98 \\
\hline Horto & 36.18 & 15.34 & 20.10 & 23.87 \\
\hline Andorinhas & 43.00 & 14.61 & 29.98 & 29.19 \\
\hline Forte São João & 45.53 & 30.55 & 17.70 & 31.26 \\
\hline Nova Palestina & 41.20 & 40.47 & 28.48 & 36.72 \\
\hline Morro do Quadro & 85.04 & 42.45 & 40.21 & 55.90 \\
\hline Jabour & 42.64 & 48.47 & 85.54 & 58.88 \\
\hline São José & 133.49 & 74.94 & 54.91 & 87.78 \\
\hline
\end{tabular}


stations, except for $\mathrm{SO}_{2}$. Meteorological variables (temperature and relative humidity) did not appear to influence air pollutant patterns in the different monitoring sites.

Mean concentrations of air pollutants like CO, $\mathrm{PM}_{10}$, and $\mathrm{NO}_{2}$ could be considered air quality indicators for the entire municipality from 2001 to 2003. Meanwhile, $\mathrm{SO}_{2}$ levels showed heterogeneous patterns among the monitoring stations, indicating that the mean concentration of this pollutant should not be applied as an air quality indicator for Vitória. However, the reason for this variation has still not been identified.

Based on the results of the air quality monitoring program in Vitória as compared to the Brazilian and WHO guidelines, air pollutant levels do not appear to be a serious environmental problem, since only $1.2 \%$ of the $\mathrm{PM}_{10}$ levels exceeded $50 \mu \mathrm{g} / \mathrm{m}^{3}$ (the Brazilian annual air quality standard). Mean $\mathrm{PM}_{10}$ for the period was $27 \mu \mathrm{g} / \mathrm{m}^{3}$, and the median values for all monitoring stations ranged from $24 \mu \mathrm{g} / \mathrm{m}^{3}$ to $37 \mu \mathrm{g} / \mathrm{m}^{3}$. Approximately $99 \%$ of the $\mathrm{PM}_{10}$ values were below the WHO guidelines for 24-hour mean $\mathrm{PM}_{10}$ 10. In fact, the $\mathrm{PM}_{10}$ levels in Vitória did not change appreciably from 2001 to 2003. According to the air quality monitoring program, Vitória municipality could be classified as having low air pollution levels for the period 2001-2003.

As an indicator, $\mathrm{PM}_{10}$ represents the particle mass that enters the respiratory tract and includes both the coarse $\left(\mathrm{PM}_{10}-\mathrm{PM}_{2.5}\right)$ and fine $\left(\mathrm{PM}_{2.5}\right)$ particles that contribute to the health effects observed in cities. In most urban environments, both coarse and fine particles are important, the former primarily produced by mechanical processes such as construction projects and road dust re-suspension and wind, and the latter primarily from combustion sources. Particle composition can often vary substantially across the same city, depending on local geography, meteorology, and specific sources 10 . However, this variability was not observed in Vitória municipality.

Particle exposure can cause a variety of health problems. Numerous studies link particle levels to increased hospital admissions and emergency room visits - and even to death from heart or lung diseases. Both long and short-term particle exposures have been linked to health problems. In this study we used outpatient data, which is not a common approach in Brazil, to evaluate the health effects of exposure to air pollutants. However, studying the human health effects of air pollution has often been challenging, because it is difficult to isolate it from other factors that also influence health, such as smoking, direct exposure to poor indoor air quality, meteorological variables, precarious social conditions, and preexisting respiratory illnesses.

The spatial distribution of asthma in children under 6 years of age showed that the districts with precarious social and environmental conditions including lack of infra-structure, local point sources of pollution such as unpaved roads, old buses, and truck traffic and/or waste incineration presented high proportional asthma rates, reaching a peak of $88 \%$ in the district of São José, followed by Jabour (59\%). The latter, besides having poor socioeconomic and environmental conditions, also suffers the direct influence of aircraft traffic and an industrial complex. The social and environmental situation is similar to that of Morro do Quadro, with an asthma rate of $56 \%$. The entire northwest region of the municipality receives heavy smog from the industrial complex during a given period of the year, generally autumn. This area also receives air pollutant emissions from industrial areas in the neighboring municipalities of Cariacica and Serra.

Mapping of asthma cases in Vitória indicated that social factors have an influence on respiratory diseases in children. This outcome may also be aggravated by local air pollution sources. This study showed the impact of some local pollution sources and poor social and environmental conditions on susceptible groups, leading to an increase in asthma rates.

These results corroborate studies in other countries that also indicate the link between environmental and health data, with an emphasis on the effects for children with asthma, including exacerbation of the inflammatory process 12. Other authors have also demonstrated the hypothesis of pollutant point sources leading to high rates of asthma in children 13,14,15. McConnell et al. 16, in a georeferenced study, examined 5,341 children ages 5 to 7 years to relate asthma and chest wheezing to place of residence, especially proximity to highways. Children living close to highways (less than 75 meters) showed a positive association with increased risk of asthma. Another study, in Juarez, Mexico, also found a positive association between $\mathrm{PM}_{10}$ concentration and outpatient asthma consultations 17 .

Pollutants can have different impacts on human health, like an increase in hospitalization or number of deaths, thus increasing aggregate costs, especially in developing countries. A prospective study in three Latin American cities (Mexico City; Santiago, Chile; and São Paulo, Brazil) gives an appropriate perspective on this problem: in the next 20 years, air pollution effects will account for 156,000 deaths, four million cases of asthma, and 300,000 physician consulta- 
tions for children, with a cost ranging from 21 to 165 billion dollars 18 .

Despite the short study period and the low mean $\mathrm{PM}_{10}$ concentration, we were able to observe a steady increase in daily outpatient treatment for respiratory diseases, compared to daily $\mathrm{PM}_{10}$ records. In 2001, with the highest number of cases (582) treated by the health services, daily $\mathrm{PM}_{10}$ was also high $\left(99 \mu \mathrm{g} / \mathrm{m}^{3}\right)$ as compared to the mean $\mathrm{PM}_{10}$ for the entire period $\left(27 \mu \mathrm{g} / \mathrm{m}^{3}\right)$. The most susceptible children probably used the health services the most. However, it was not possible to directly associate the exposure to pollutant levels, due to some confounders that it was not possible to investigate in this study, e.g., socioeconomic variables and exposure time.

The use of secondary data always produces some study limitations. In this study, the use of UPB was a new source of health data with some limitations. Information on the children's nutritional status, parents' habits (e.g., smoking), housing conditions, family history of respiratory illness, and time since moving to the area are some examples of data that could improve explanation of the results. The quality of UPB data for diagnosis poses another limitation. The data were extremely condensed, without a thorough description of patients' signs and symptoms, without the number of visits by the children to the outpatient services, and with no assessment as to the severity of asthma and pneumonia cases. Such information would help define a health indicator capable of better reflecting social and environmental conditions, thus simplifying the environmental health surveillance process.

This study provided an approach to spatial distribution of asthma in children, identifying the worst period of the year (autumn) and the districts with the highest asthma rates according to treatment figures in municipal outpatient services. It also produced a cartographic basis (GIS) for the Municipal Health and Environmental Secretary that will facilitate a more thorough investigation of the districts identified by the current study.

Based on the air quality results, Vitória can be classified as having a low level of air pollution. However, several studies have shown that numerous adverse effects have been linked especially to airborne particulate matter at even lower concentrations.

Installation of a $\mathrm{PM}_{10}$ monitoring station is recommended in the northwest part of the city to obtain better details on the magnitude of exposure to air pollutants in neighborhoods with poor socioeconomic conditions.

Knowledge on the spatial distribution of respiratory diseases in the pediatric population in Vitória allows decision-makers to implement specific low-cost local measures in the short and mid-term. This study has emphasized the need to strengthen the municipal health and environmental secretariats to integrate actions and responsibilities and improve the Environmental Health Surveillance Program at the local, regional, and national levels.

\section{Resumo}

No Brasil, o crescimento da poluição do ar em áreas urbanas tem sido responsável pelo aumento das doenças respiratórias em crianças e idosos e a principal causa das internações hospitalares. O presente estudo tem como objetivos avaliar os níveis de poluição do ar no Município de Vitória, Espírito Santo, Brasil, em relação à legislação nacional e o recente padrão proposto pela Organização Mundial da Saúde (OMS) e, a distribuição espacial dos casos de asma atendidos nos ambulatórios das unidades básicas de saúde no Município de Vitória. Um estudo epidemiológico descritivo foi realizado para o período de 2001 a 2003 para me- nores de seis anos. O Sistema Geográfico de Informação foi usado para identificar o padrão de distribuição de asma na municipalidade. Os resultados mostraram que os níveis de poluição de ar no município são relativamente baixos, quando comparados à legislação nacional e aos padrões de qualidade do ar recém propostos pela OMS. Os três bairros com as maiores taxas de asma foram São José, Jabour e Morro do Quadro.

Doenças Respiratórias; Poluição do Ar; Sistemas de Informação 


\section{Contributors}

H. A. Castro participated in the study design, database construction, statistical analysis, and drafting of the manuscript. S. Hacon participated in the study design, data collection, database construction, statistical analysis, and drafting of the manuscript. W. L. Junger participated in the database construction and statistical analysis. R. Argento participated in the data collection, database construction, GIS application, and mapping. C. F. Mello participated in the data collection, database construction, and statistical analysis. N. Castiglioni Júnior and J. G. Costa participated in the field visits and analysis of the results.

\section{Acknowledgments}

This study received financial support from the Strategic Development Program at the Sergio Arouca National School of Public Health, Oswaldo Cruz Foundation (ENSP/FIOCRUZ), in partnership with the Vitória Municipal Health Secretariat and with logistic support from Zeneide Caneva Gagno. The State Environmental Secretariat (SEAMA) and State Environmental Institute (IEMA) provided the air quality database, with technical support from Nilson Castiglioni Júnior and José Gustavo da Costa. The authors wish to acknowledge the logistic field support provided by the State Health Secretariat through Maria de Fátima Bertollo Dettoni and Diana de Oliveira Frauches. The authors also acknowledge the collaboration and technical support from the Health Surveillance Secretariat of the Brazilian Ministry of Health.

\section{References}

1. Comisión Económica para América Latina y el Caribe. De la urbanización acelerada a la consolidación de los asentamientos humanos en América Latina y el Caribe: el espacio regional. Santiago: Comisión Económica para América Latina y el Caribe/Centro de las Naciones Unidas para los Asentamientos Humanos; 2000.

2. Lacy R, López M, Ortega JA. Conciencia ciudadana y contaminación atmosférica: estado de situación (México). Santiago: Comisión Económica para América Latina y el Caribe; 2000.

3. Nel A. Air pollution-related illness: effects of particles. Science 2005; 308:804-5.

4. Polosa R, Salvi S. Particulate air pollution from motor vehicles: a putative proallergic hazard? Can Respir J 1999; 6:436-41.

5. Hiltermann TJN, Stolk J, van der Zee SC, Brunekreef B, Bruijne CR, Fischer PH, et al. Asthma severity and susceptibility to air pollution. Eur Respir J 1998; 11:686-93.

6. Secretaria Nacional de Ações Básicas de Saúde, Ministério da Saúde. Estatísticas de mortalidade, 2000. http://portal.saude.gov.br/saude (accessed on $08 / \mathrm{Jan} / 2007$ ).
7. Instituto Estadual de Meio Ambiente e Recursos Hídricos. Relatório da qualidade do ar da região da Grande Vitória, ano de 2004. Cariacica: Instituto Estadual de Meio Ambiente e Recursos Hídricos; 2005.

8. Ministério da Saúde. http://tabnet.datasus.gov. br/cgi/idb2003/matriz.htm (accessed on 08/ Apr/2006).

9. Brasil. Resolução no. 003. Conselho Nacional de Meio Ambiente (CONAMA) de 28 de junho de 1990. Diário Oficial da União 1990; 22 ago.

10. World Health Organization. WHO Air quality guidelines global update 2005. Report on a Working Group Meeting, Bonn, Germany, October 1820, 2005. Copenhagen: World Health Organization; 2005.

11. Barcellos C, Coutinho K, Pina MF, Magalhães MMAF, Paola JCMD, Santos SM. Inter-relacionamento de dados ambientais e de saúde: análise de risco à saúde aplicada ao abastecimento de água no Rio de Janeiro utilizando Sistemas de Informações Geográficas. Cad Saúde Pública 1998; 14:597605. 
12. Timonen KL, Pekkanen J. Air pollution and respiratory health among children with asthmatic or cough symptoms. Am J Respir Crit Care Med 1997; 156(2 Pt 1):546-52.

13. Brauer M, Hoek G, van Vliet P, Meliefste K, Fischer $\mathrm{PH}$, Wijga A, et al. Air pollution from traffic and the development of respiratory infections and asthmatic and allergic symptoms in children. Am J Respir Crit Care Med 2002; 166:1092-8.

14. Gauderman WJ, Avol E, Lurmann F, Kuenzli N, Gilliland F, Peters J, et al. Childhood asthma and exposure to traffic and nitrogen dioxide. Epidemiology $2005 ; 16: 737-43$.

15. Nicolai T, Carr D, Weiland SK, Duhme H, von Ehrenstein $\mathrm{O}$, Wagner $\mathrm{C}$, et al. Urban traffic and pollutant exposure related to respiratory outcomes and atopy in a large sample of children. Eur Respir J 2003; 21:956-63.
16. McConnell R, Berhane K, Yao L, Jerrett M, Lurmann F, Gilliland F, et al. Traffic, susceptibility, and childhood asthma. Environ Health Perspect 2006; 114:766-72.

17. Hernández-Cadena L, Téllez-Rojo MM, SanínAguirre LH, Lacasaña-Navarro M, Campos A, Romieu I. Relación entre consultas a urgencias por enfermedad respiratoria y contaminación atmosférica en Ciudad Juárez, Chihuahua. Salud Pública de Méx 2000; 42:288-97.

18. Bell ML, Davis DL, Gouveia N, Borja-Aburto VH, Cifuentes LA. The avoidable health effects of air pollution in three Latin American cities: Santiago, Sao Paulo, and Mexico City. Environ Res 2006; 100:431-40.

Submitted on 09/May/2006

Final version resubmitted on 30/May/2007 Approved on 01/Jun/2007 